\title{
Was the Supreme Court right to change the law on the right to a speedy trial?
}

\section{Léonid Sirota ${ }^{\star}$}

In $R v$ Jordan,${ }^{1}$ the Supreme Court of Canada held, by a 5-4 majority and over the vigorous disagreement of the concurrence, that criminal prosecutions in which a trial does not conclude by a set deadline will be presumed to breach the right to be tried within a reasonable time, protected by section 11(b) of the Canadian Charter of Rights and Freedoms. The acceptable length of proceedings set out in the decision is of 18 months from the day charges are laid for cases that proceed without a preliminary inquiry, and 30 months otherwise. The Crown can still show that exceptional circumstances outside of its control have arisen and can explain - and excuse - a case taking longer than that, but unless it does so, a stay of proceedings will be the automatic consequence of such delay. Meanwhile, an accused will be able to show that delay below these ceilings is unconstitutionally unreasonable, but only by demonstrating not only that the delay is "markedly" greater than reasonable, but also that he or she diligently sought to have the case heard sooner.

While the majority is scathing of the "culture of delay" that in its view plagues the Canadian criminal justice system, and emphatic about the need to change this culture, its decision has been much criticized, as I will explain below. For my part, I agree that Jordan raises significant questions regarding the consistency of the majority's decision with constitutional text, the soundness of its approach as a matter of policy, the justification set out for it, and the choice to implement this approach by judicial fiat. And yet, there is more to be said in its defence than critics allow.
Consider, first, whether the majority's approach is consistent with constitutional text. Section 11(b) of the Charter provides that "[a]ny person charged with an offence has the right ... to be tried within a reasonable time." The concurrence in effect argues that this text requires treating reasonableness as a standard and prohibits translating it into a bright-line rule, as the majority does. (Justice Cromwell doesn't quite put the point in this way: he says that the majority's approach is inconsistent with "purpose of the right" - which is consistent with the Supreme Court's tendency to treat constitutional text as secondary to the "purposes" it is deemed to implement.) The majority, in my view, does not make much of an effort to address this argument.

To be sure, the idea of reasonableness normally refers to a standard, not a rule. But - precisely for that reason-the constitutional text that entrenches this standard calls for judicial elaboration or, as modern originalists would say, construction. ${ }^{2}$ In other words, the constitutional text itself does not give answers to the questions that arise in the course of adjudication. It must be supplemented by judicially-developed doctrines. The question is whether the courts can make bright-line numerical rules part of their doctrines. (And it is only one part; the majority is right to say that the concurrence somewhat overstates the degree to which the test is a numerical one.) Or are such rules simply inconsistent with the meaning "reasonableness"? This is not an easy question; at the very least, I do not think that its answer is as clear cut as the concurrence suggests. The fact that reasonableness requirements have not thus far been construed in this way in Canada or abroad, is significant, 
but hardly dispositive. It is unfortunate that the majority does not address this issue.

The concurrence is right, however that the majority's approach to cases that fall below its ceilings is a departure from the constitution's text. The text provides a right "to be tried within a reasonable time" - not a right "to be tried within a time that is not markedly unreasonable provided that one has been diligent." Presumably the majority introduces these additional requirements in order to incentivize defence counsel to contribute to the cultural change which it seeks. But while understandable, this motivation cannot justify an obvious inconsistency with the constitutional text. That said, the issues of whether there can and ought to be a "ceiling" above which the burden of proof shifts to the Crown, and just what ought to happen below that ceiling, are distinct. It may be that the majority is right about the first even if it is wrong about the second.

\section{$* * *$}

Beyond textual concerns, it is not clear whether the majority opinion provides the right approach to the issue of delays in the criminal justice system as a matter of policy. Jordan came under sharp criticism as soon as it was delivered. Michael Spratt was especially scathing, arguing that " $t]$ he Supreme Court's latest decision pays lip service to the constitution while doing little to improve the pace of Canadian justice." ${ }^{3}$ Joanna Baron has defended "incrementalism," in preference to the majority's approach that risks allowing too much time for trials in provincial courts, and not enough in the superior courts. ${ }^{4}$ Lauren Heuser called "the ceiling on trial times ... worryingly firm," especially in that it prevents courts from making exceptions on account of the "the depravity of an offence," writing that "[m] ore than a few people will be uncomfortable when suspected perpetrators of serious crimes walk free on perceived legal technicalities."

Ms. Heuser's prediction, at least, seems to have been vindicated, especially in Québec. There, stays entered in a number of highprofile cases have caused considerable concern and prompted calls for the Charter's "notwithstanding clause" to be invoked. ${ }^{6}$ Indeed a bill to this effect has recently been introduced in the National Assembly ${ }^{7}$ - even though, as Maxime St-Hilaire's contributions to this issue show, such a bill will not be constitutionally effective.

Beyond the legal difficulties the invocation of the "notwithstanding clause" would face, the suggestion that the right to a speedy trial ought to be ignored in particularly egregious cases is easy enough to dispose of. The Charter does not speak of "a right to be tried within a reasonable time, except for those accused of depraved offences." The Jordan majority is quite right to say that only the complexity of the legal or factual issues, rather than the gravity of the charge, can justify a prosecution taking longer to conclude. Those who think otherwise need to amend the constitution, not seek to escape it.

Yet the underlying critique - that (relatively) firm ceilings are not an appropriate response to the problem of delay due to the infinite variety of the cases to which they will be applied - is serious. I cannot reject it out of hand here. But I would like to raise a question for those who endorse it. It is, quite simply this: what makes you think that a few tweaks to an approach that appears to have thoroughly failed are enough? Ms. Heuser acknowledged that "[w]hile one can question whether this ruling was the best way to light a fire under Canada's court system, few would dispute that a fire needed to be lit." ${ }^{2}$ The Jordan concurrence does not seem to address the majority's claim that the system suffers from a "culture of delay" directly - which seems like a concession. The concurrence does argue that the majority's radical approach is unnecessary, because the case isn't even a close one under the one that prevailed before Jordan, at least as modified in its opinion. Yet both the trial court and the unanimous Court of Appeal thought that the delay which the concurrence thinks is clearly unconstitutional was quite alright. I too tend to prefer incrementalism, but the time for incrementalism on this issue may well have run out.

Now, that doesn't mean that what the Supreme Court did was right. Just because something must be done, and $x$ is something, it doesn't follow that $x$ must be done. But what other options were there? Mr. Spratt agreed that 
"[c]hange is indeed needed" while insisting that "we should hold little hope that a cynical judgment from the Supreme Court will change anything." This was, in retrospect, too pessimistic, ${ }^{10}$ and I think it was always unfair to describe the majority opinion in Jordan as "cynical," despite its flaws. It is easy enough for a blogging defence lawyer to rail against the practices of police and prosecutors, and the policies of governments, and to accuse the courts of complicity. Yet such tirades, even if justified, hardly answer the question of what a court ought to do when it does recognize the existence of a serious problem, however belatedly.

In my view, the most clearly problematic aspects of the Jordan decision are not substantive, but procedural. A court embarking on a controversial remaking of an important area of the law, especially one that is of genuine concern to the public, would do well to base its decision on solid evidence, and to explain it to potential critics. In other words, its decision-making process must meet certain - high - standards. It seems to me that the Jordan majority did not discharge this burden. The concurrence castigates the majority for having imposed its presumptive ceilings without having been asked to do so by the parties and without adversarial debate. It adds that there was limited evidence in the record about both the current state of affairs, which the majority characterized as "a culture of delay", and about the potential consequences of the new approach. These criticisms are justified.

As mentioned above, the majority's decision is a fairly radical departure from the existing law. Indeed, the majority is clear that it wants to change the way all the actors in the criminal justice system operate, and that governments may well have to spend more to meet their new, or at least newly articulated, constitutional obligations. While I have no doubt that the majority did ponder this decision seriously, I do not think that it has done enough to articulate its rationale. Given the magnitude of the change it was considering, and the fact that it was not canvassed by the parties in argument, the Court should, it seems to me, have re-opened the argu- ment and invited the parties to make submissions that would have addressed its concerns. Indeed, I wonder if the Court could have invited Attorneys General, only one of whom (Alberta's) intervened, to participate in the debate.

Alternatively, the Court could have decided the case on the basis of the existing framework (perhaps modified as suggested by the concurrence), and suggested in its reasons that it would, in a future case, be willing to entertain submissions on whether that framework should be overhauled in the future. This would of course have delayed the implementation of any proposed changes, but it would also have allowed for any decision on whether these changes are a good idea to be made on the basis of a record put together and tested by the parties, and not only of the majority's own limited research. ${ }^{11}$

Speaking of the research, Mr. Spratt argues that the majority "did not do what every elementary school student is taught to do - show his or her work." 12 He calls the majority's framework "a product of judicial alchemy and ... entirely unprincipled." ${ }^{3}$ I would not go so far, but an opinion that doesn't show its authors' work makes them vulnerable to such charges. As I wrote after the Court's decision in Carter v. Canada (Attorney General)," "I am happy to assume that the Court did its work, but others may not be, and neither they nor I should have to take that on faith." ${ }^{15}$ Sure, the reasons in Jordan are very long, but the majority could have produced some sort of annex to explain the results of its research much better than it has done. It is a question of transparency, and arguably even simple respect for the public over which the Court is exercising a considerable power.

$* * *$

Putting these significant concerns about the majority's decision-making process to one side, there remains the even more fundamental question of the legitimacy of reforming the law and the legal culture by judicial fiat. Sometimes the answer to the question of what one is to do, even in the face of a situation crying out for action, is nevertheless "nothing". The courts' role, like that of other institutions, is limited. The Jordan 
concurrence suggested that numerical ceilings should only be imposed, if at all, by legislation. Ms. Baron was also of that view. The concurrence also criticized the majority for overturning settled precedent. So did Ms. Heuser. Both these critiques amount to a contention that the majority overstepped the proper judicial remit. I am not persuaded of this.

I agree that the majority's decision is essentially legislative. The fact that it felt the need to lay out a transitional framework underscores this, as transitional provisions are common in statutes, but almost unheard-of in judicial decisions, except in the limited form of suspended declarations of invalidity-and their legitimacy too is sometimes challenged. ${ }^{16}$ But that alone isn't enough to show that it is not appropriate for a court to make such a decision. Some judicial decisions are essentially legislative. One that comes to mind is Andrews v. Grand \& Toy Alberta $L t d .{ }^{17}$ in which the Supreme Court imposed a hard cap on the amount of damages that can be awarded for pain and suffering in personal injury cases. Pace such legal philosophers as Ronald Dworkin and F.A. Hayek, courts do on occasion introduce new rules of law that cannot be derived in any straightforward way from either legal principles or from the practices prevalent in society, and most people seem prepared to live with these decisions. Legislatures often accept them even when they could change or reverse them.

So it is not enough to say that the Court effectively made new law and thus usurped the legislatures' prerogative. And of course, even if the legislatures had enacted statutes to impose ceilings on delays in the justice system, the courts would still have the last word on their constitutionality. Ruling on ceilings in the context of a constitutional challenge to a statute is almost certainly better from a process standpoint, as such a case would likely feature a substantial record of the sort that was missing in Jordan. But in terms of institutional legitimacy, these two cases would not be that different. Indeed, a ruling on the constitutionality of statutory ceilings would come with complications of its own, because it would confront the courts with very difficult questions under section 1 of the Charter, which are avoided when, as in Jordan, the constitutional challenge is not aimed at a rule or regulation. Most fundamentally, can legislative ratification save delays that are intolerable if produced by a "culture of delay" under section 1 of the Charter as "reasonable limits" to the section 11(b) rights?

Ultimately, though, the issue is not whether, in a perfect world, the legislatures would act to limit delays, and how the courts should respond to such legislation. Rather, the issue is that until they were confronted with the Jordan judgment, legislatures and governments had done nothing at all to remedy the problem of delays that are unconstitutional, not to mention unconscionable. Assuming that such delays are indeed endemic, and that there is a "culture of delay"which no one denies - the issue is thus the existence of widespread and ongoing violations of the constitutional rights of thousands of people. These violations have to be remedied. Sure, it is not the courts' job to pursue policy objectives to which the elected officials fail to attend. But it is not mere policy that is at stake here. Sure, courts should beware of disregarding the limits on their power because doing so undermines the Rule of Law. But doesn't systematic disregard for the Constitution undermine the Rule of Law too? If the governments will not bring themselves in conformity with their constitutional obligations, shouldn't the courts try to make them? And if the courts do not, who will?

All this is to say, I am not convinced that the majority opinion in Jordan is as fatally flawed as its critics believe. Admittedly, its interpretation of the Charter is not beyond question; its chosen solution to what is admittedly a grave problem is questionable; the process it followed in reaching its decision was flawed; and perhaps, all things considered, it should not have endeavoured to do more than mitigate that problem's worst manifestations. But it is far from clear that this is so. It is difficult to get the government to comply with its constitutional obligations-and someone has to do it. 


\section{Endnotes}

* Auckland University of Technology Law School; this essay is adapted from blog posts originally published as Léonid Sirota, "Keeping Time, Time, Time" (21 July 2016), Double Aspect (blog), online: $<$ https://doubleaspect.blog/2016/07/21/keepingtime-time-time/> and Léonid Sirota, "Someone's Got to Do It" (27 July 2016), Double Aspect (blog), online: <https://doubleaspect.blog/2016/07/27/ someones-got-to-do-it/>.

12016 SCC 27, [2016] 1 SCR 631 [Jordan].

2 See generally Lawrence B Solum, "Originalism and Constitutional Construction" (2013) 82:2 Fordham L Rev 453; Lawrence B Solum, "The Interpretation-Construction Distinction" (2010) 27:1 Const Commentary 95; Randy E Barnett, "Interpretation and Construction" (2011) 34:1 Harv JL \& Pub Pol'y 65.

3 Michael Spratt, "Expect Delays: Right to a Speedy Trial” (19 July 2016), Michael Spratt: Criminal Defence Counsel (blog), online: <www. michaelspratt.com/law-blog/expect-delays-rightto-a-speedy-trial>.

4 Interview of Joanna Baron by Jim Brown, "The Supreme Court of Canada 'got it wrong' when it tried to speed up trials, says legal society director" (17 July 2016) on CBC Radio: The 180 with Jim Brown, online: <www.cbc.ca/ radio/the $180 /$ be-kind-and-don-t-recline-stopbeing-so-cynical-about-electoral-reformand-the-problem-with-this-song-1.3677753/ the-supreme-court-of-canada-got-it-wrongwhen-it-tried-to-speed-up-trials-says-legalsociety-director-1.3677964>.

5 Lauren Heuser, "The Problem with a Firm Ceiling on Trial Times", National Post (20 July 2016), online: <news.nationalpost.com/full-comment/ lauren-heuser-the-problem-with-a-firm-ceilingon-trial-times $>$.

6 See e.g. Josée Legault, "Arrêt Jordan : aux grands maux les grands remèdes", Le Journal de Montréal (7 April 2017), online: <www.journaldemontreal. com/2017/04/07/arret-jordan--aux-grands-mauxles-grands-remedes>; Brian Myles, "LaprèsJordan: confusion au tribunal", Le Devoir (10
April 2017), online: <www.ledevoir.com/societe/ justice/496018/1-apres-jordan-confusion-autribunal>; "Une autre accusation de meurtre abandonnée en raison de l'arrêt Jordan", Le Soleil (19 May 2017), online: <www.lapresse.ca/le-soleil/ justice-et-faits-divers/201705/19/01-5099867une-autre-accusation-de-meurtre-abandonneeen-raison-de-larret-jordan.php>.

7 Bill 890, An Act to ensure sound administration of justice in order to maintain public confidence in the justice system, 1st Sess, 41st Leg, Quebec, 2017.

8 Heuser, supra note 5.

9 Spratt, supra note 3.

10 See e.g. "Province implements 'triage' system to help ease delays that plague Alberta courts", The Edmonton Journal (21 October 2017), online: $<$ edmontonjournal.com/storyline/provinceimplements-triage-system-to-help-ease-delaysthat-plague-alberta-courts $>$; Alison Crawford, "Criminal courts scramble to meet Supreme Court's new trial timelines", $C B C$ News (11 February 2017), online: <www.cbc.ca/news/ politics/jordan-decision-courts-justicedelays-1.3973981>; "More judges, prosecutors hired to reduce delays in Quebec's justice system", CBC News (27 March 2017), online: <www.cbc. $\mathrm{ca} /$ news/canada/montreal/quebec-hires-judgesprosecutors-1.4043058>.

11 See Jordan, supra note 1 at para 106 ("we conducted a qualitative review of nearly every reported s. 11(b) appellate decision from the past 10 years, and many decisions from trial courts").

12 Spratt, supra note 3.

13 Ibid.

142015 SCC 5, [2015] 1 SCR 331.

15 Léonid Sirota, "The Two Halves of the Glass" (10 February 2015), Double Aspect (blog), online: $<$ https://doubleaspect.blog/2015/02/10/the-twohalves-of-the-glass/>.

16 Robert Leckey, "Suspended Declarations of Invalidity and the Rule of Law" (12 March 2014), UK Constitutional Law Association (blog), online: $<$ https://ukconstitutionallaw.org/2014/03/12/ robert-leckey-suspended-declarations-ofinvalidity-and-and-the-rule-of-law/>.

17 [1978] 2 SCR 229, 83 DLR (3d) 452. 
